\title{
The sustainable urban design on the example of Oświęcim
}

\author{
Krystyna Paprzyca, ${ }^{1, *}$ \\ ${ }^{1}$ Institute of Urban Design, Faculty of Architecture, Cracow University of Technology
}

\begin{abstract}
The quality of the urban environment determines a lasting relationship between a man and his place of residence. Sustainable management of the urban spaces is crucial as it directly affects their quality. The article analyses the results of the sustainability regarding spatial, socio-economic, technical and environmental aspects, which are one of the many conditions that contribute to the proper functioning of urban life. They also influence the quality of life and residence in the urban environment. There are different ways of expressing the development of the cities defined by specific indicators. They focus mainly on development of the quality of life - social, economic and environmental development. The sustainable urban design is related to issues connected with the form and spatial management. This topic is presented on the example of the city of Oświęcim - the Old Town district with the surrounding area.
\end{abstract}

\section{Introduction}

Currently, many Polish cities undergo transformations aimed at the improvement of the quality of life and residence.

It should be remembered that local authorities play a crucial role in decisions related to the transformations. They should be directed to the protection of the urbanised environment, maintenance of the inner-city areas in a non-deteriorated condition and in accordance with their intended use. The city should also implement activities related to justified investing in a given area.

All analyses preceding specific decisions in the downtown areas allow to learn about their strengths and weaknesses, opportunities and threats. Advantages such as a high standard of infrastructure, a high standard of construction or green technology, positively distinguish districts. The weaknesses of a given area such as communication difficulties, a small number of car parks or an unfavourable neighbourhood make it difficult to use the district in accordance with its purpose and thus distinguish it negatively. Many negative phenomena characterise individual districts of the city or its fragments.

They include:

- the decrease in the quality of the urban environment,

- loss of the character of the district,

\footnotetext{
*Corresponding author: krystyna.paprzyca@xl.wp.pl, krystyna.paprzyca@pk.edu.pl
} 
- limited contacts between people,

- degradation and capitalisation in relation to the whole district or building complexes.

This phenomenon is observed mainly in downtown areas of pre-war and post-war buildings,

- negligence of local business and services,

- higher number of unemployed,

- high level of traffic and congestion,

- production of large amounts of waste,

- excessive water and energy consumption,

- low air quality,

The consequences of this phenomena are:

- intensive growth of urban areas outside the city to agricultural and even forest areas, resulting in the degradation of the natural environment,

- outflow of people from urban and city centers to the city outskirts,

- reduced number of investments,

- loneliness, emptiness, noman's neighborhoods,

- hooliganism, vandalism,

and many more $[1,2,4,5]$.

The daily use of cars results in lifeless districts, boring and monotonous without people walking through the streets. The possibility of meeting and talking to people helps in establishing relationships with the surrounding world and connecting with a given place of the residence. Experiencing the presence of people offers a rich and varied sensory experience.

In addition, the buildings in many districts are in poor technical condition as materials and technologies applied in construction have become obsolete. The area is deteriorating, falling out of the city rhythm due to the loss of its potential, e.g. commercial or communication. There is an inability to accept new functional programs or communication links between the workplace and the inhabited area [6].

When the district becomes unattractive for the residents, it declines and becomes abandoned by the wealthy inhabitants. The remaining residences of a well-off group are occupied by the next social group able to afford them. Such processes cause transformations in the social structure of the neighbourhood.

These burdens may cause concern among the residents.

The primary function of the city is to provide housing spaces and public areas such as streets, squares and parks. Midtown areas are areas of the compact urban form. Their potential is connected with their location, so they become attractive places to live in $[3,8]$.

By using the optimal conditions of the place and counteracting the threats, it is possible to create optimal living conditions within urban areas.

\section{Characteristics of sustainable development. Sustainability in the sense of a friendly living environment}

The experience and achievements of the European Union in the planning and development of the cities and the increase in the quality of the urban environment can be applied in towns, inner-city and urban districts [12].

All reports regarding the future of the cities contain issues related to promoting durable, sustainable development and the improvement of the quality of life and the environment. Those issues appear to be crucial in promoting European cities. The economic growth of the city, its quality and the surrounding environment are the foundations of sustainable development. The idea of sustainable development is to harmonise, balance and coordinate 
three factors: social, economic and environmental development. The principles of sustainable development perceive the city as a complex, connected, dynamic system of intertwined processes of social, economic and spatial development [1].

The vision of sustainable urban development combines the actions of the planners, designers and managers who aim to create a beautiful, healthy and socially integrated environment. It promotes valuable economic growth, protection of the areas against the uncontrolled expansion of new buildings, high quality and well-planned transport system and public infrastructure as well as respect for the cultural heritage of the place and the society $[2,3]$.

The notion of sustainable development facilitated the formation of two key strategies: "Compact city" approach which opens up to compacted forms, cost-effective, efficient infrastructure, and "short cycles strategy", which emphasises the local environment system and reduces the ecological footprint [1].

The article aims to analyse the relationship of urban forms to environmental, technical, socio-economic and ecological expectations that allow to create optimal living conditions.

\section{Oświęcim - the Old Town District. Spatial arrangement}

Oświęcim is an old town with the tradition that dates back 800 years. The Old Town District, its urban layout and monuments are a testimony to history. Until the renovation, this part of the city was characterised by a poor technical condition of the buildings and underinvestment of technical infrastructure. The uneven development of the town has led to social, economic and environmental problems.

Nowadays, the attention of the local authorities is directed on the improvement of the image of the Old Town and the reduction of the damages connected with the environment.

In recent years the Old Town District was modernised, The Market Square and surrounding technical infrastructure (Photo 1) were renovated.

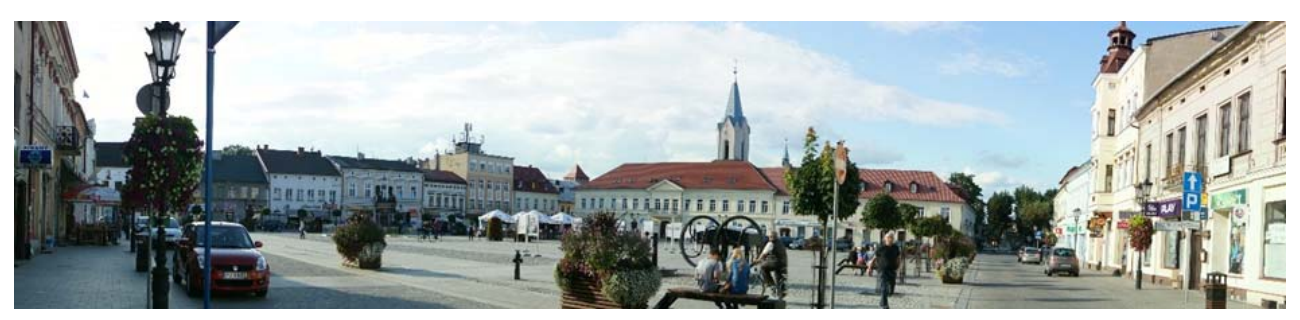

Photo 1. Modernised market Square in Oświęcim (author's picture 2016).

There are residential and service buildings located in the area of the Market Square. Among them, as many as 41 come from before 1945, 12 were built in 1946-1989. The age of the buildings created the need to carry out renovations, reconstructions, modernisation and exchange related to the technical condition of the buildings, and their equipment. The materials applied during these activities are environmentally friendly, which reduces or eliminate negative impacts on the climate [10-12].

The City authorities conduct various activities that prevent decapitalization, the devastation of buildings, and their negative impact on the environment. 


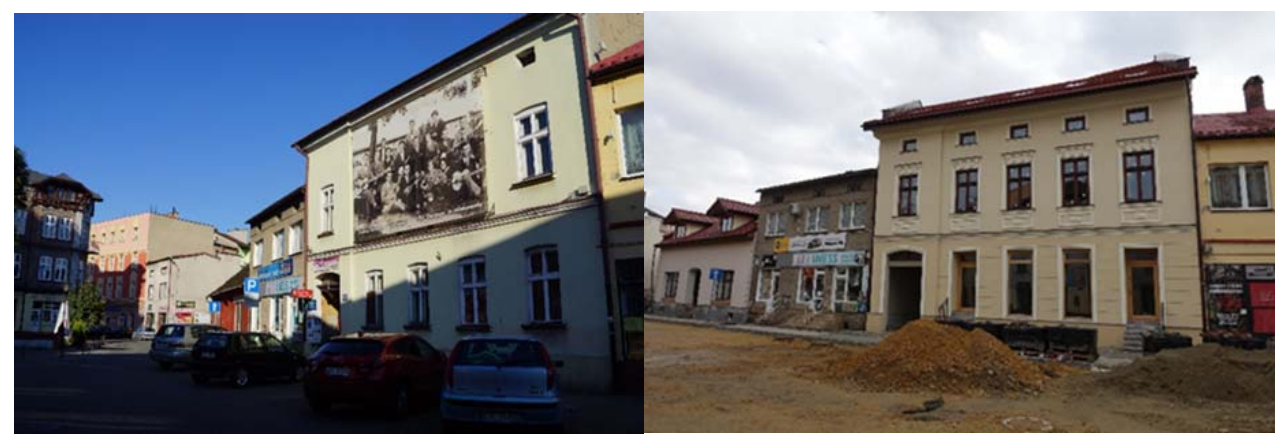

Photo 2. Mały Rynek tenement, the year 2014 and 2017 (author's picture 2014, 2017).

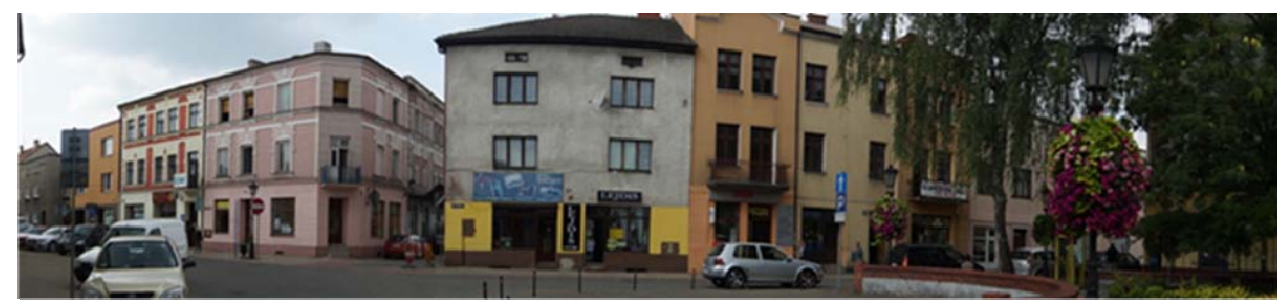

Photo 3. Oświęcim. Devastated corner house at Klasztorna street and Mały Rynek (author's picture 2013).

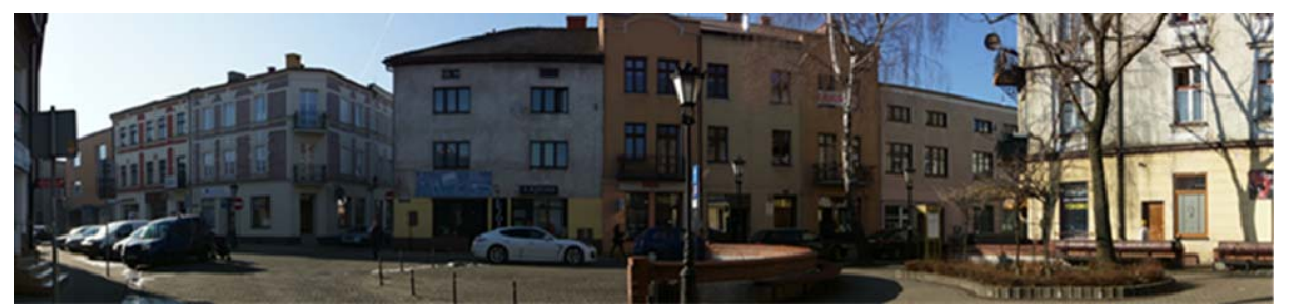

Photo 4. Oświęcim. Renovated corner house at Klasztorna street and Mały Rynek (author's picture 2015) [10].

There is a constant demand for more space as well as the quality and quantity of the apartments in Oświęcim. It is necessary to continue the existing strategy of the city, focused on social demand, primarily aimed at improving the quality of public spaces: streets, squares, parks, places of social activities $[3,8]$.

They should be characterised by the atmosphere and the identity of the place, and the vitality of the area provided through various forms of activity.

Green public spaces are connected with the activity of people. Nature is an essential component of the quality of life in urban housing areas. The proximity of green spaces influences the level of physical activity and health of the residents.

Places, available to all social groups are significant in creating a healthy local community. Parks and playgrounds are places of rest or children's play, which positively affect the quality of the life and living environment (Photo 5).

The current actions of the municipal government are focused on the activation of areas along the Soła River. It is important that tourists, who are presently concentrated mainly in the area of the Auschwitz Museum, reach the Oświęcim's Old Town in higher numbers. This idea may be implemented in the future owing to the unique Ghost Bridge project of Jarosław Kozakiewicz $[11,12]$. 


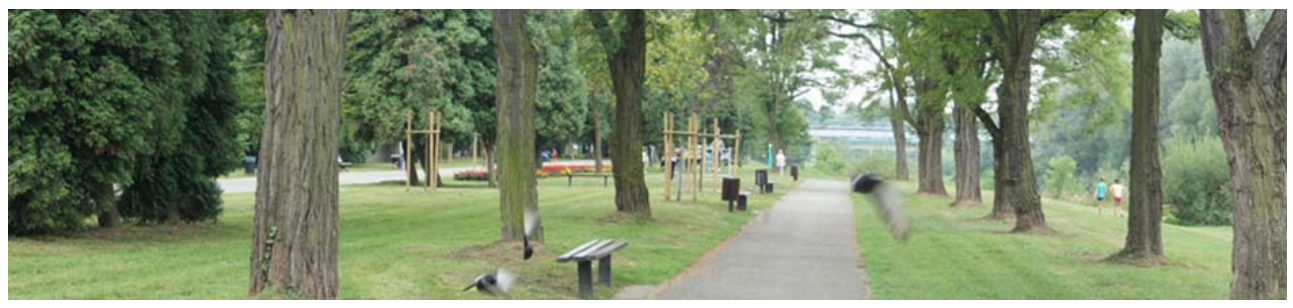

Photo 5. Development of the areas along the Sola river.(author's own picture 2015).

\section{Oświęcim - the Old Town District. Socio-economical aspects}

The city has to be a place suitable for living. Sustainability presented in the article is related to the aspects of social equality, the balance of the local community, public capital, social justice, social inclusion, and cohesion. Social equality is inseparably connected with easy access to local services and the possibility of enjoying various pleasures. A community that is sustainable represents a certain level, a social capital, and cohesion understood as pride and local bond, security, stability and durability. It provides a good quality of life. Social sustainability is reflected in a high level of satisfaction with housing, the neighbourhood and the assessment of the local environment $[4,5,7]$.

Access to services within the limits of the neighbourhood is a fundamental feature for many groups living in a particular place, also for the unemployed, older people, and young families. It plays a significant role in social life. The perception of security, especially in the green areas is the primary condition of use, aimed at its maintenance.

The environmental and social dimension is the essence of sustainability, but economics is also a key feature that allows the cities to exist.

The priorities of the local self-government are related to sustainable development in the social aspect, that is the constant improvement of the quality of the housing conditions, employment and the use of free time, thus the improvement of the quality of life of the residents. Those actions should also take into account proper levels of security and standards of the natural environment.

Oświęcim, like many other medium-sized cities in Poland, faces numerous problems connected with the outflow of the population and ageing of the inhabitants. The authorities of the city try to prevent the phenomena of migration to the outskirts of the town. The area of the Old Town is inhabited by 2018 people, which is $5.12 \%$ of the total population of the city. [11] The population structure is characterised by a decrease in the number of people in pre-working and working age, which indicates the ageing of the population. This trend has been continuing since 2010 [12].

Considering the number of inhabitants living in a given area, one can state a large concentration of pathological behaviours and crime. The Old Town is characterised by the highest values of indicators related to recorded offences. Therefore, it can be considered as a concentration of pathological behaviours. The unemployment of the residents is also higher than in other parts of the city and indicates the massive scale of the problem. Therefore, all the actions aimed at maintaining social balance are important. The activities undertaken by the City and the Social Housing Association of Oświęcim, that re-develop "empty tenements of unknown ownership" positively affect the population structure of this area. The efforts of the Social Housing Association of Oświęcim also support housing needs of people who, due to their income, are located in a specific segment of the social structure, and they contribute to filling the gap in the middle-income and middle-age group of the people living in the Old Town District [10-12]. 


\section{Oświęcim - the Old Town District - technical and environmental aspect}

Most of the priorities set by the European Union and related to housing construction concern the quality of life and new building materials.

The urban environment plays an important role in these priorities with the conditions it offers for the residents. Buildings consume energy for heating, which is a source of gas and chemical emissions. According to the studies, the increase of the energy efficiency allows saving a minimum of $20-30 \%$ of energy (sometimes up to $50 \%$ ) [5].

Unfortunately, utility objects and infrastructure services are not interested in sustainable construction, because its primary task is to display a given product or service.

"The building's operating costs account for as much as $84 \%$ of which up to $75 \%$ is heating and hot water production. ... the construction costs constitute $11 \%$ and demolition $0.5 \%$ of the costs of "building's life". The costs of renovations during the 50 -year period constitute approximately $4.5 \%$ of the "living costs" of the structure. The issue of high technical quality of buildings becomes important because in Poland a significant share of housing resources is old, and new buildings lose $1 \%$ of their value per year. The goal is to eliminate additional costs associated with the operation of the building that has a negative impact on the natural environment. The building should not reduce the quality of life of the residents and contribute to the loss of value of natural resources, i.e. it should not be capital-consuming $[5,10]$.

Owing to the City's strategy focused on the use of more compact, functionally differentiated forms, the need to travel may be reduced. This action contributes to the reduction of the car as a mean of transport and promotes more sustainable ways of travelling such as walking, cycling or public transport. Of course, it all depends on changing people's habits.

Environmental threats force the solutions of more compact urban forms, which concentrate the functions and reduce the use of cars, thus reducing the harmful car emissions. However, compact urban structures reduce the area of open spaces. This threat causes an increase in interest in a variety of green spaces. In a sustainable environment, public green areas also fulfil many tasks: they reduce air temperature, improve thermal comfort in the summer, and are a buffer against pollution and noise as well as reduce wind power. Green spaces enhance the effect of the island of heat, cooling buildings for free, thus reducing the use of air conditioning, energy consumption and $\mathrm{CO}_{2}$ emissions. Therefore it is crucial to include green spaces within the city space not only regarding the size of those spaces but also their composition $[11,12]$.

\section{Conclusions}

The downtown areas of the city of Oświęcim have a potential to be an attractive place of residence. The intensified and multifunctional use of the existing space contributes to the improvement of the quality of the living environment and the willingness of various social groups to live in this area.

The goal of the sustainable urban design is to strive for the optimal quality of the urban structure. Spatial, social, economic and environmental values of the city shape its image and determine whether it develops or remains stagnant. The aim of creating a proper city image is to gain new investors, support new and existing companies, and sustain the development. As a result, the city will be spatially functional, with a healthy physical environment and attractive equipment.

There are many issues that include urban renewal focused on sustainable urban design: 
- the improvement of the quality of public spaces. Revitalization and modernisation of buildings and technical infrastructure in the Old Town;

- increasing the offer concerning recreation and tourism in the areas along the Soła River.

- maintaining the identity and culture of the place;

- use of the potential of the location of Oświęcim at the intersection of transit transport routes of national and voivodship importance.

The benefits for the city are associated with many aspects. Some of them include:

- better accessibility, effective use of the existing urban communication infrastructure, a convenient transport system for various users: drivers, passengers, cyclists, pedestrians;

- less dependence on the use of the car, which reduces the emission of pollutants; friendly communication for pedestrians influences the improvement of the physical condition of the residents;

- better quality of public transport services;

- the rational policy of the city related to urban areas: residential or green, increase of the building intensity. The balance of jobs, the service offer and the number of inhabitants is of great importance;

- openness to the business environment.

The city is characterised by proper planning that creates a safe, attractive environment for its residents. Owing to the appropriate management, the inhabitants can safely live, work and play. The actions of the authorities are also directed at a competitive economy thanks to which the inhabitants receive an optimal quality of life and environment. Through various activities, the city aims to improve the quality of space and the quality of the environment. Created surrounding is attractive.

The man, his health and safety are the main objectives.

The city of Oświęcim implements actions focused on sustainable development. It is demonstrated by the following indicators: the number of inhabitants is gradually growing, as well as the number of visitors to the city and level of income of the residents. Also, the level of property values is growing.

Over the past year, the city has been promoted in the Forbes ranking from eighth to third position. "Most new ventures are being created in the areas belonging to Synthos (former Dwory Chemical Company), which today function as an industrial cluster. There are several companies there, and two more are currently building their factories: Italian IPB (metal pressing) and Sofir (repairs of presses and technological lines). Synthos offers fully developed, industrial areas located along the access roads, with a total area of 100 hectares "...." New companies are also developing in the 45-hectare Municipal Economic Activity Zone and in the Oświęcim Business Incubator where more than 50 companies have located their offices. The zone is situated on the outskirts of Oświęcim, by the national road No. 44 (Tychy-Zator-Skawina-Kraków), which is the bypass of the city centre. Further development of Oświęcim will be facilitated by the commenced expansion of the city zone (part of it is covered by the privileges of the special economic zone). The investment will cost PLN 16.4 million. The city will receive over 9 million from the Małopolska Regional Operational Program. "The most attractive cities for business - Forbes [13, 14].

\section{References}

1. A. Baranowski, (Sustainable design in architecture, Arkady, Warszawa 1998)

2. J.M. Chmielewski, (Theory of urban planning in the design and planning of cities, Warszawa 2001)

3. E. Cichy-Pazder, (The Humanistic basis for the composition of cities, Politechnika Krakowska, Kraków 1998,dańskiej, Gdańsk 1998) 
4. New urban planning - a new quality of life, Proceedings of the III Congress of Polish Urban Planning, Urbanist Library, 14, Warszawa, Public space card (edited by L. Biegański, G. Buczek, S. Gzell, A. Kowalewski, T. Markowski, E. Cichy-Pazder 2009)

5. K. Paprzyca, (Harmonizing urban development of urban areas - selected issues, Monograph 417, Kraków, Wydaw. Politechniki Krakowskiej)

6. K. Paprzyca, (Rational use of urban space in medium-sized cities - one of the conditions for their development, in Multi-author monograph Contemporary housing environment, Texter 2015, Wydawnictwo Texter ISBN: 978-83-7790-795-5, Contemporary housing environment Texter https://www.texterbooks.com > E-book > Społeczno-ekonomiczne) (access 16.07.2016)

7. E. Przesmycka A. Frąckiewicz, A. Garanty, A. Sieradzka, M.A. Stańkowski, Stalowa Wola. The city of the past - the future of the city, Series: Architektura \& Dizajn, Wydawnictwo: Muzeum Regionalne w Stalowej Woli, Nr 1, 2014)

8. A.Wallis, (City and space, Warszawa 1977)

9. OŚWIĘCIM. New apartments are waiting for rent - Oświęcim Online www.oswiecimonline.pl/10642-oświęcim-nowe-mieszkania-czekają-na-wynajem.html

10. OTBS Oświęcim saves the Old Town - dziennikpolski24.plwww.dziennikpolski24.pl/ tag/otbs-Oswiecim-ratuje-stare-miasto/

11. Development strategy for the city of Oświęcim for the years 2014-2020, http://web.um.oswiecim.pl/strategia-uwagi/strategia_rozwoju_miasta_oswiecim_ na_lata_2014-2020.pdf (access 16.07.2016)

12. Cities on the way to sustainable development - PwC (https://www.pwc.pl/pl/biuroprasowe/.../miasto_szans_opisy_dobrych_praktyk.pdf p. 3)

13. https://www.forbes.pl/rankingi/miasta-najbardziej-atrakcyjne-dla-biznesu/nrlbnyg

14. K. Paprzyca, Czasopismo Techniczne, 115(3), 41-52 (2018) 